\author{
小林 勲*・清水正賢*・稲葉晋一*2 ·成出貴一*2
}

\title{
Estimation and Verification of Melting Zone Profile in Blast Furnace
}

\author{
Isao Kobayashi, Masakata ShImIzu, Shin-ichi InABA, and Kiichi Narita
}

\section{Synopsis :}

In order to detect the melting zone profile in a blast furnace, a tracer method has been developed. Including tracers uniformly distributed in a given ore layer and analyzing the change of the concentration in tapped metal, the melting process of tracer-containing layer can be estimated. And the profile of melting zone is obtained by transforming the melting ratio of tracer-containing layer to the melting radius at every height in the furnace. The change of the tracer concentration in tapped pig iron is analyzed assuming that the molten metal in the furnace drops smoothly to the hearth and the dilution of the tracer in the hearth acts on a system of first order lag. As the tracer, an Fe-P alloy was used. The melting temperature was obtained as $1350^{\circ} \mathrm{C}$ by the softening and melting test under load with elevated temperature.

The tracer method was applied to Kakogawa No. 1 blast furnace $\left(3090 \mathrm{~m}^{3}\right)$, whose operating conditions were almost same as those of the shutting down, and the profile of melting zone was estimated. To verify the estimated results, the furnace was quenched with water and the internal state was investigated. The estimated profile of melting zone is in fairly good agreement with the inner profile of softening and melting zone observed after the dissection.

\section{1. 緒}

\section{言}

我が国におけるこれまでの高炉解体調查により，高炉 炉内には軟化融着带の存在することが確認され犯， その 位置と形状が高炉操業の安定性と経済性に大きく影響す ると考兄ら礼ている. 以来，この軟化融着带形状を前提 として高炉プロセスの各種解析が進められるとともに, 稼動高炉内の軟化融着带形状を推定する努力が重㸚られ ている. 数学的モデルに基づく方法 ${ }^{23)}$ はこの推定法の 一つであるが，ここで推定された結果は実炉で検証され る必要がある。一方, 炉内状況を直接的倹出する方法 として，炬内へ送り込み方式の垂直ゾンデを插入する方 法4)5やトレーサーを投入する方法6)があるが，これらの 方法ではセンサーあるいはトレーサーの炣内に拈ける正 確な位置の把握が難しい，また，従来のトレーサー法は 半径方向のある一点の溶け落ち位置を求めるものであ り, 滴下帯形状を求めるには 2 回以上のトレーサーの投 入が必要となる.

ここでは，Fe-P 合金をある一層分の鉱石層内に均一 に分散させて炬内に投入し，出銑時のリン濃度の変化か ら $\mathrm{Fe}-\mathrm{P}$ 合金添加層の炬内に沏ける滴下開始位置の半 径方向分布を推定する方法を述べる。この方法をぺレッ
トを多量配合する加古川 No. 1 高灯 $\left(3090 \mathrm{~m}^{3}, 1981\right.$ 年 3 月 5 日吹き止め) の吹き止め直前の操業に適用して 滴下带の形状を推定した。吹き止好後にこの商炉の解体 調查を行い, 滴下带形状の推定絬果之解休断湎の観察結 果を比較することにより本推定法の妥当性を検颜した。

\section{Fe-P 合金投入による 滴下帯形状の推定方法}

\section{$2 \cdot 1$ 推定方法}

$\mathrm{Fe}-\mathrm{P}$ 合金を添加した鉱石曆が炉内を降下して軟化融 着帯部に達すると，Fig. 1 の慔式㘠に示すようにこ の鉱石層は軟化融着带の内側から溶け落七る，溶け落ち 後，高濃度のリンを含んで炉休に滴下した浴銑は炉床部 に残留する溶銑によつて希釈される。ここで，

（1）軟化融着带部で溶け落ちた溶銑は速やかに炉术 まで滴下する。

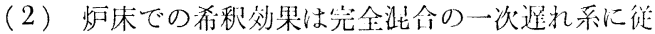
ら.

と仮定する。

鉱石層が炬頂最上層から $\mathrm{j}$ 層までに溶け洛もる显を $X_{\mathrm{j}}$ とすると, $\mathrm{j}-1$ 層から $\mathrm{j}$ 層に移行する同の溶け落ち 量は（1）式で表される.

$$
\Delta X_{\mathrm{j}}=X_{\mathrm{j}}-X_{\mathrm{j}-1}
$$

弨和 56 年 11 月本会满演大会にて発表 绍和 57 作 3 月 12 日受付 (Received Mar. 12，1982)

* (㧣) 神戸製鋼所中央研究䜣 (Central Research Laboratory, Kobe Steel, Ltd., 1-13-18 Wakinohama-cho Chuo-ku Kobe 651)

*2 (㧣) 神戸製鋼所中尖研究浙 工博 (Central Research Laboratory, Kobe Steel, Ltd.) 


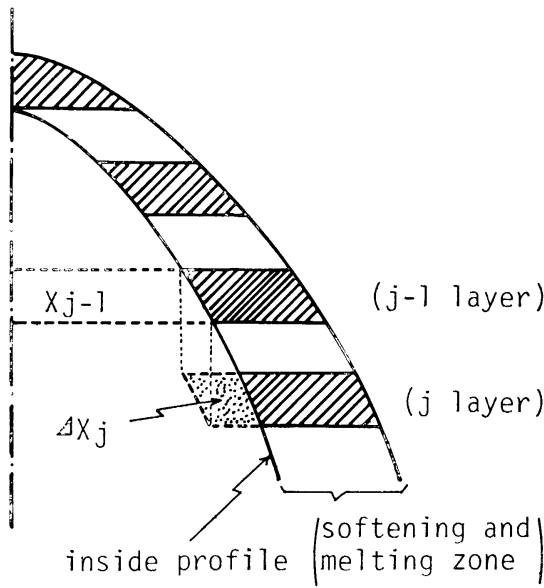

$Y_{j}:$ melting weight up to $\mathrm{j}$ layer

$J X_{\mathrm{j}}$ : differnce of melting weight between $(\mathrm{j}-1)$ and $\mathrm{j}$ layer.

Fig. 1. Schematic diagram of melting down for tracer-containing layer at softening and melting zone.

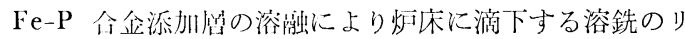
ン濃安は半径方们に分布を有して上昇するが，半径方向 に平均したリン濃度の上䏬は（2)式となる。したがつて 炉术へ流入する壮均りン濃度は（3)式で表される.

$$
\begin{gathered}
J C=\underset{C_{\mathrm{B}} \cdot O_{\mathrm{B}}+\omega_{\mathrm{T}}}{\omega_{\mathrm{T}} \cdot \beta} \times J X_{\mathrm{j}} \times \begin{array}{c}
1 \\
v_{\mathrm{c}} \cdot V_{\mathrm{i}}
\end{array} \\
C_{\mathrm{i}}-C_{\mathrm{i}}^{0}+J C \ldots \ldots \ldots \ldots \ldots \ldots \ldots \ldots \ldots \ldots \ldots \ldots \ldots \ldots \ldots
\end{gathered}
$$

灯术部におけみりンと溶銑の物質収支から（4)，（5)式 が得られる。

$$
\begin{aligned}
& \frac{d\left(W C_{0}\right)}{d t}=V_{\mathrm{i}} C_{\mathrm{i}}-V_{0} C_{0} \\
& \frac{d W}{d t}=V_{\mathrm{i}}-V_{\mathrm{0}}
\end{aligned}
$$

ここで

$C:$ リン濃度 $(\mathrm{kg}(\mathrm{P}) / \mathrm{kg})$

$C_{\mathrm{i}}^{0}: \mathrm{Fe}-\mathrm{P}$ 合金無添加時の流入りン濃度 $(\mathrm{kg}(\mathrm{P}) /$ $\mathrm{kg}$ )

$C_{\mathrm{B}}:$ コークスベース $(\mathrm{kg})$

$O_{\mathrm{B}}:$ ore $/$ coke 比 $(-)$

$V:$ 溶銑流量 $(\mathrm{kg} / \mathrm{h})$

$W:$ 炉内残銑量 $(\mathrm{kg})$

$\Delta X_{\mathrm{j}}$ ：鉱石層が $\mathrm{J}-1$ 層から $\mathrm{j}$ 層に移行する間の浴 け落ち量 $(\mathrm{kg} / \mathrm{ch})$

$t:$ 時問 $(\mathrm{h})$

$\omega_{\mathrm{T}}: \mathrm{Fe}-\mathrm{P}$ 合金添加量 $(\mathrm{kg})$

$v_{\mathrm{c}}:$ 装入間隔 $(\mathrm{h} / \mathrm{ch})$

$\beta: \mathrm{Fe}-\mathrm{P}$ 合金中のリン濃度 $(\mathrm{kg}(\mathrm{P}) / \mathrm{kg}(\mathrm{Fe}-\mathrm{P}))$

(添字) i : 流入, o : 流出.

Fig. 2(a) に示すような滴下带形状の場合に，炉内 残銑量の初期値を变えて炉床へ供給される溶銑中のリン 濃度 $\left(C_{\mathrm{i}}\right)$ と出銑時のリン濃度 $\left(C_{\mathrm{o}}\right)$ の変化を試算した 例を Fig. 2(b) に示す. この場合, 出銑時の最大濃度 を示す時間はトレーサー層の溶銑完了時間にほぼ一致 し, 炉内残銑量の初期值によつて出銑時の最大濃度や濃 度の低下速度の異なることがわかる。

次に, $\mathrm{Fe}-\mathrm{P}$ 合金をトレーサーとして炉内に投入して， 出銑時のリン濃度の変化から滴下帯形状を検出する方法 を述べる．時間 $[o, t]$ 間に炉床へ供給されるリンの量 $(S(t))$ は $(4)$ 式の関係から(6)式のように表すことが できる.

$$
\begin{aligned}
S(t) & =\int_{0}^{\mathrm{t}} V_{\mathrm{i}} C_{\mathrm{i}} d t \\
& =W(t) C_{0}(t)-W(0) C_{0}(0)+\int_{0}^{\mathrm{t}} V_{0} C_{0} d t \cdots(6)
\end{aligned}
$$

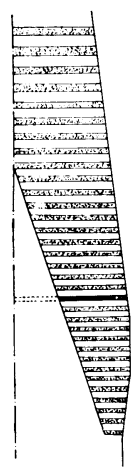

(a)



(b)

Elapsed time after beginning
of tracer layer melting ( $h)$

lig. 2. Schematic diagram of melting zone (a) and estimation of the changes of tracer concentration in hot metal (b). 
一方，炉床へ流入する溶銑の平均リン濃度 $\left(C_{\mathrm{i}}\right)$ は (3)式で表されるので， $S(t)$ は (7) 式のようにも表さ れる。

$$
\begin{aligned}
S(t) & =\int_{0}^{\mathrm{t}} V_{\mathrm{i}}\left(C_{\mathrm{1}}^{0}+\Delta C\right) d t \\
& =\int_{0}^{\mathrm{t}} V_{\mathrm{i}} C_{\mathrm{i}}^{0} d t+\int_{0}^{\mathrm{t}} V_{\mathrm{i}} \Delta C d t
\end{aligned}
$$

Fe-P 合金添加層の溶融によるリンの炉床への供給 量 $\left(S_{\mathrm{m}}(t)\right)$ は(7) 式の右辺第 2 項であるので, $S_{\mathrm{m}}(t)$ は (8)式で与兄られる.

$$
\begin{aligned}
S_{\mathrm{m}}(t) & =\int_{0}^{\mathrm{t}} V_{\mathrm{i}} \Delta C d t \\
= & S(t)-\int_{0}^{\mathrm{t}} V_{\mathrm{i}} C_{\mathrm{i}}^{0} d t
\end{aligned}
$$

したがつて，(6)式の $S(t)$ を(8)式に代入することに より， $S_{\mathrm{m}}(t)$ を求めることができる.ここで，(6)式中 の炉床部残銑量の変化 $(W(t))$ は $(5)$ 式を積分して $(9)$ 式のように算出した.

$$
W(t)=W(0)+\int_{0}^{t}\left(V_{\mathbf{i}}-V_{0}\right) d t
$$

炉床一の溶銑流入速度 $\left(V_{\mathrm{i}}\right)$ は装入間隔から $(10)$ 式のよ らに求められる.

$$
V_{\mathrm{i}}=C_{\mathrm{B}} /\left(C_{\mathrm{R}} \cdot v_{\mathrm{c}}\right)
$$

炉床からの流出速度 $\left(V_{0}\right)$ は受銑時の実測値を用いるこ とが望ましいが，実測できない場合は各出銑ごとの出銑 速度を(11)式のように近似して用いることにした。これ は加古川 No. 3 高炉の実測值を参照して出銑速度を出 銑開始後の経過時間に関する 2 次式で表し，タップごと の受銑量と収支させたものである.

$$
V_{\mathbf{0}}=3 W_{\mathrm{p}}(2 \Theta-\theta) \theta / 2 \Theta^{3}
$$

ここで

$C_{\mathrm{R}}:$ コークス比 $(\mathrm{kg} / \mathrm{kg})$

$W_{\mathrm{p}}:$ 該当タップの受銑量 $(\mathrm{kg})$

$0:$ 出銑開始後の経過時間 $(\mathrm{h})$

$\Theta:$ 出銑時間 $(h)$

$\mathrm{Fe}-\mathrm{P}$ 合金添加層の炬内投入後の装入回数を $\mathrm{j}$ とする と, この層が炉内 $\mathrm{j}$ 層の位置に達する時間は(12)式で表 され， $\mathrm{j}$ 層までの溶融滴下率 $\Delta M_{\mathrm{j}}$ は $(8)$ 式の結果を用 いて(13)式で計算できる.

$$
\begin{aligned}
& t_{\mathrm{j}}=\mathbf{j} \times v_{\mathrm{c}} \\
& \Delta M_{\mathrm{j}}=S_{\mathrm{m}}\left(t_{\mathrm{j}}\right) / S_{\mathrm{m}}(\infty) \\
& =\left(\int_{0}^{t_{\mathrm{j}}} V_{\mathrm{i}} \Delta C d t\right) /\left(\int_{0}^{\infty} V_{\mathrm{i}} \Delta C d t\right)
\end{aligned}
$$

ここで, (13)式の分母の積分の上限は出銑中のリン濃度 が Fe-P 合金投入前のレベルに戻るまでの時間を採用 すればよい。

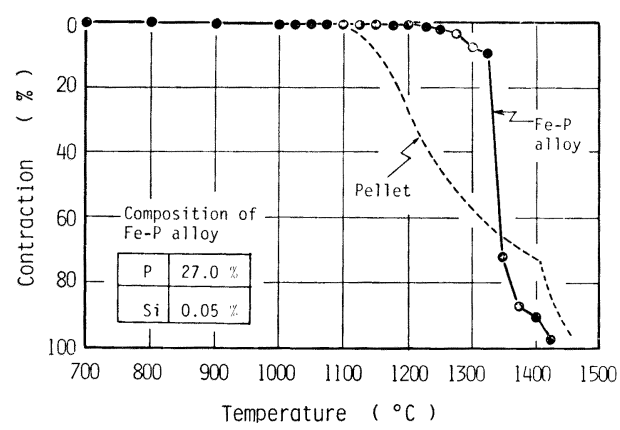

Fig. 3. Softening and melting behaviour of Fe-P alloy examined under load with elevated temperature.

炬内に抢ける $\mathrm{j}$ 層の位置は各装入ごとの銥石層とコー クス層の装入体積と炉体形状から算出できる。炣内が水 平な層状構造で $\mathrm{Fe}-\mathrm{P}$ 合金添加層が中心部から溶け落 ちていく場合には，炉内 $\mathrm{j}$ 層の位置における溶け落ち半 径 $\left(R_{\mathrm{m}, \mathrm{j}}\right)$ は (14) 式のように求められる.

$$
\Delta M_{\mathrm{j}}=\left(R_{\mathrm{m}, \mathrm{j}}\right)^{2} /\left(R_{\mathbf{0}, \mathrm{j}}\right)^{2}
$$

より

$$
R_{\mathrm{m}, \mathrm{j}}=V \Delta M_{\mathrm{j}} \cdot R_{\mathbf{0}, \mathrm{j}}
$$

$R_{0, \mathrm{j}}$ : 炉内 $\mathrm{j}$ 層の鉣石層位圆に打ける灿内半径

\section{$2 \cdot 2$ Fe-P 合金の性状}

$\mathrm{Fe}-\mathrm{P}$ 合金は粒度を $10 \sim 20 \mathrm{~mm}$ に調整したものを使

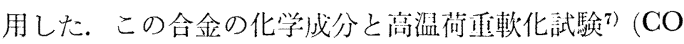
: $30 \%, \mathrm{~N}_{2}: 70 \%$, 連綾香温) の結果とペレットの収縮 率変化を Fig. 3 江示す. Fe-P 合金は $1350^{\circ} \mathrm{C}$ 付近の


ちに至るまでの収縮やふくれはペレットよりも小さいこ とがわかる。このように，Fe-P 合金の溶村落七溫度は 鉱石類の溶け落ち温度に近く，トレーサーとしてのリン は純粋なリンとして投入されるので注济少全に溶鋔中に 移行するものと考光られる。来た，多昷に使用しても操 栄上の熱的補傥を核とんぞ考虑する必要がなく，通父性 に対する影響も小さいと推察される。

\section{3. 高炉操業への適用}

Fe-P 合金の加古川 No. 1 高枃への投入は，吹き止

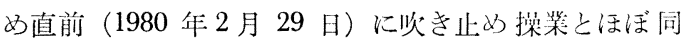

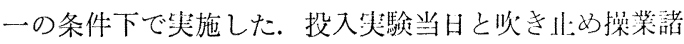
元を Table 1 に，装入線下 $1.6 \mathrm{~m}$ にあるシャフトガス サンプラーによつて测定した温度分布を Fig. 4 に示し た。これらから $\mathrm{Fe}-\mathrm{P}$ 合金投入洔の操栄は吹き止的時 と注涪同様の操策状況にあることがわかる。

$\mathrm{Fe}-\mathrm{P}$ 合金は, $\mathrm{C}_{I} \downarrow \mathrm{C}_{I I} \downarrow \mathrm{O}_{I} \downarrow \mathrm{O}_{I I} \downarrow$ 装入のある一千 


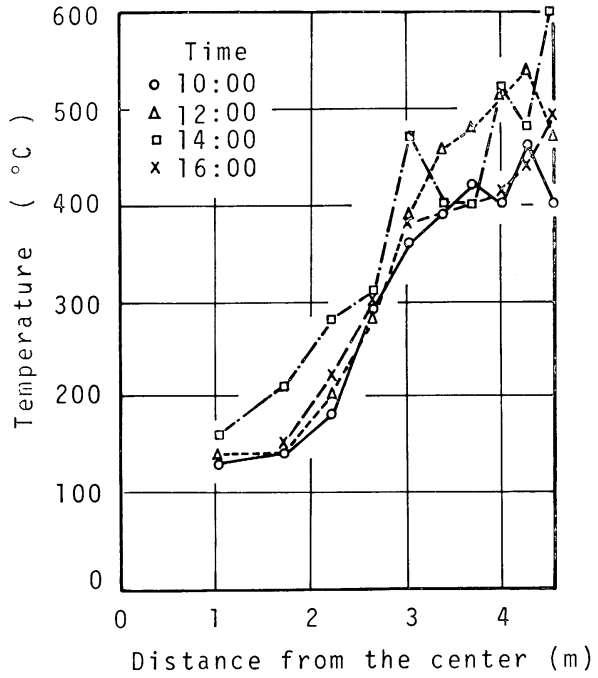

(a) $\Lambda t \mathrm{Fe}-\mathrm{P}$ charging

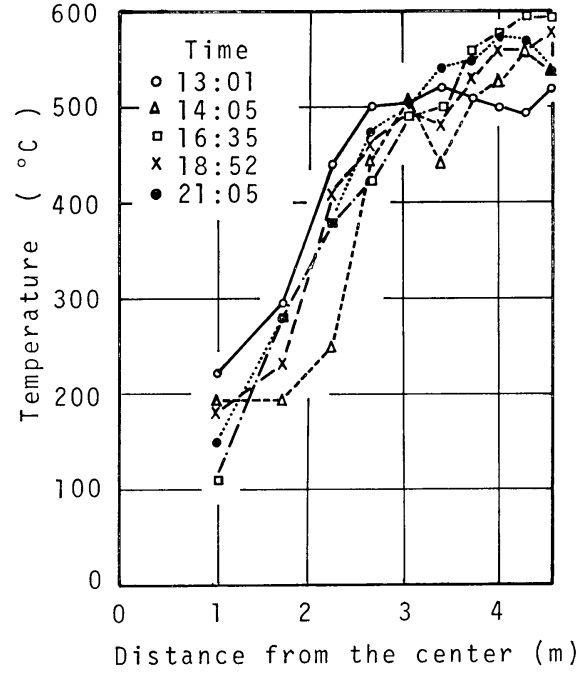

(b) At shutting-down

Fig. 4. Temperature distributions of gas measured by shaft gas sampler.

Table 1. Operating conditions at $\mathrm{Fe}-\mathrm{p}$ alloy charging and at the shutting down of Kakogawa No. 1 blast furnace.

\begin{tabular}{lcc}
\hline \multicolumn{1}{c}{ Operation } & Fe-P alloy charging & Shutting down \\
Blast volume $\left(\mathrm{Nm}^{3} / \mathrm{min}\right)$ & 3746 & 3800 \\
Blast temperature $\left({ }^{\circ} \mathrm{C}\right)$ & 756 & 720 \\
Blast moisture $\left(\mathrm{g} / \mathrm{Nm}^{3}\right)$ & 33 & 30 \\
Coke raie $(\mathrm{kg} / \mathrm{t})$ & 582 & 580 \\
Oil rate $(\mathrm{kg} / \mathrm{t})$ & 0 & 0 \\
Pellet content $(\%)$ & 70.5 & 70.5 \\
Charging interval $(\mathrm{min} / \mathrm{ch})$ & 15.8 & 16.0
\end{tabular}

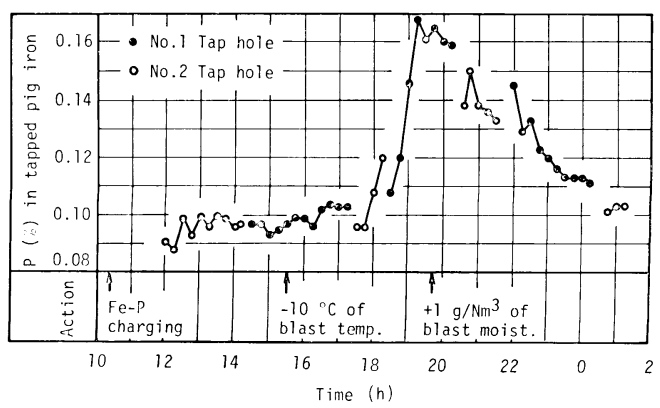

Fig. 5. Change of phosphorus concentration in tapped pig iron after charging $\mathrm{Fe}-\mathrm{P}$ alloy.

ージの $\mathrm{O}_{\mathrm{I}}$ と $\mathrm{O}_{\mathrm{II}}$ にそれぞれ $800 \mathrm{~kg}$ ずつ，鉱石類が貯 鉣榑から受鉙ホッパー送りのベルトコンベア上へ切り出 されると同侍にその銨不上へ投入した，実物大模型装入 物分布实駼 ${ }^{8)}$ や高炉火入れ前の壙充時の観測によれば, この投入才法により Fe-P 合金は炉内で注均一に分 散される。

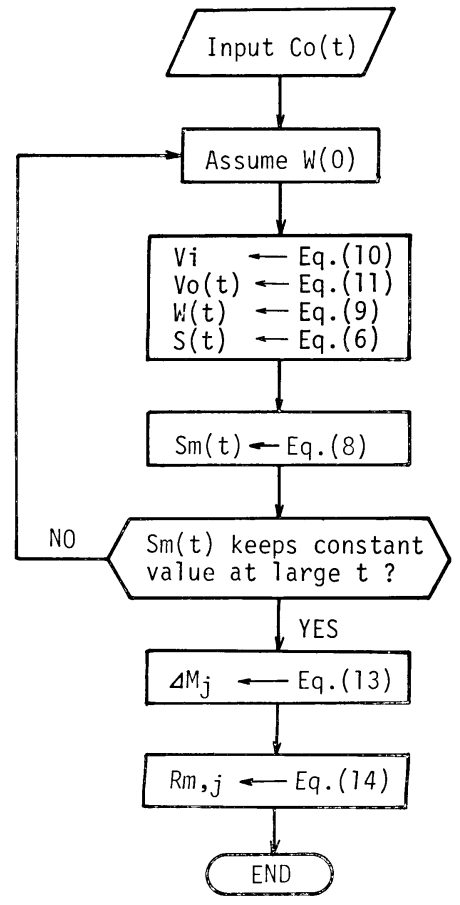

Fig. 6. Flow chart for estimating the profile of melting zone.

$\mathrm{Fe}-\mathrm{P}$ 合金投入後の溶銑中のリン濃度の変化とこの実 験中にとられた操業アクションを Fig. 5 に示す．操業 アクションは送風温度の $10^{\circ} \mathrm{C}$ 低下と, 送風湿度の $1 \mathrm{~g}$ $/ \mathrm{Nm}^{3}$ の増加のみで, ほぼ一定条件が維持されていた。 
出銑は軸対称位置にある 2 本の出銑口から交互に行い， ほぼ連続出銑である、溶銑のサンプリングは $15 \mathrm{~min}$ 問 隔で実施した．溶銑中のリン濃度は 16 時 30 分頃から 上昇しはじめ, 19 時 15 分には最大濃度が現れている. なお, 16 時 30 分以後で出銑開始直後のサンプルにはリ ン濃度の不連続がみられるが，これは出銑桶中に前回に 出銑した際の溶銑が残留していたためと考えられ，解析 データからは除外した.

次に解析結果について述べる。計算手順を Fig. 6 に 示すが，まず $S_{\mathrm{m}}(t)$ は以下のようにして求めた。

(1) $W(0)$ を仮定して与える.

(2) $V_{\mathrm{i}}$ を(10)式から， $V_{0} を(11)$ 式から算出する.

(3)上記の $V_{\mathrm{i}}, V_{0}$ を用いて $(9)$ 式より $W(t)$ を算出 さる.

(4)次に Fig. 5 に示与 $C_{0}$ の実測值を用い, $(6)$ 式に したがつて $S(t)$ を求める. このとき $C_{0}$ の変化 は数式で表示できないので, 積分計算にはシンプソ ン法を用いた。

(5)以上の算出値から (8)式にしたがつて $S_{\mathrm{m}}(t)$ を算 出した. ここで， (8)式中の $C_{1}^{0}$ には $\mathrm{Fe}-\mathrm{P}$ 合金 投入前の溶銑中のリン濃度の平均值を用いた.

これまでの計算過程で重要な值は, Fig. 2(b) に示 したように $W(0)$ である. しかし，そ机を正確に把握 することは困難なので，次のようにして求めたＦ Fe-P 合金添加層の溶融完了後は, 物質収支から $(8)$ 式の $S_{\mathrm{m}}$ $(t)$ は一定值で推移するはずである. しかし， $S_{\mathrm{m}}(t)$ の計算時に残銑量の初期值が適合していないとリンの物 質収支があわず，過不足が生じる，そこで，実験データ の解析時にこの初期值を変化させて, $\mathrm{Fe}-\mathrm{P}$ 合金添加層 の溶融完了後は $S_{\mathrm{m}}(t)$ が一定値で推移する值を探索し た. 本実験ではこの值は $390 \mathrm{t}$ と推定された.

このようにして求めた炉床へ供給されるリンの量 $S$ $(t)$ と Fe-P 合金の溶け落ちにより供給されるリン の量 $S_{\mathrm{m}}(t)$ の変化を Fig. 7 亿示与. Fe-P 合金添加

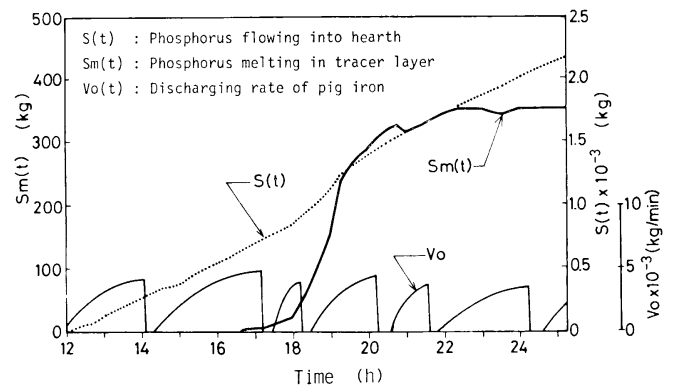

Fig. 7. Estimation of melting weight of phosphorus as the tracer.

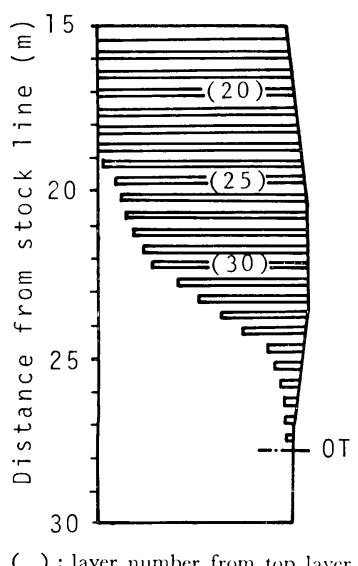

Fig. 8. Estimated profile of melting zone.

Table 2. Estimating conditions of melting level profile.

$\begin{array}{lcc}\text { Coke base } & 21400 & \mathrm{~kg} / \mathrm{ch} \\ \text { Ore/coke ratio } & 2.841 & - \\ \text { Bulk density of ore } & 2292 & \mathrm{~kg} / \mathrm{m}^{3} \\ \text { Bulk density of coke } & 486 & \mathrm{~kg} / \mathrm{m}^{3} \\ \text { Charging interval } & 15.8 & \mathrm{~min} / \mathrm{ch} \\ \text { Average contraction of charging } & 10 & \% \\ \text { material during the descent } & & \end{array}$

層は装入の約 $6 \mathrm{~h}$ 後に㵜下しはじめ, 出銑中のリン濃度 が最大となる $9 \mathrm{~h}$ 後には約 $70 \%$ が溶け落ちており, 10 h $30 \mathrm{~min}$ 後にほぼ全星溶け落七たことがわかる. Fe-P 合金添加層の溶け落ちには $4 \mathrm{~h} 30 \mathrm{~min}$ を裂しており, 装入速度から考光ると 17 層分に相监与る。また，Fig. 7 の $S_{\mathrm{m}}(t)$ の最終做から得的るリンの步留りは 83 \%であつた.

$\mathrm{Fe}-\mathrm{P}$ 合金の溶村落ちによるリンの供給出 $S_{\mathrm{m}}(t)$ の 変化から(13)，(14)式を用いて求めた灿内各層ごとの滴 下半径の分布, 与なおり滴下開始位罚の半径方向分布 をFig. 8 亿示す.この訃算で使用した原料の允てん条 件を Table 2 に示寸. 装入物の装密度は装入物分布実 験 ${ }^{8)}$ から得た数值である. 装入物の灯内降下圠生じる 収縮もしくは压縮 (Average contraction) は, 装入時の 体積と装入から羽ロレベルに遊するまでの装入问数の実 濝から平均 $10 \%$ 之推篮した。

Fig. 8 の推定結果をみると, 鉱石層の溶汁落ちはシ ヤフト下部の炬腹との境界近くで開始し, 妆ロレベルで ほぼ完了していることがわかる。

\section{4. 解体調查による断面観察結果との比較}

Fe-P 合金の投入によつて求めた滴卜開始レベルと, 加古川 No. 1 高灯の解休洞查による軟化融着带形状の 


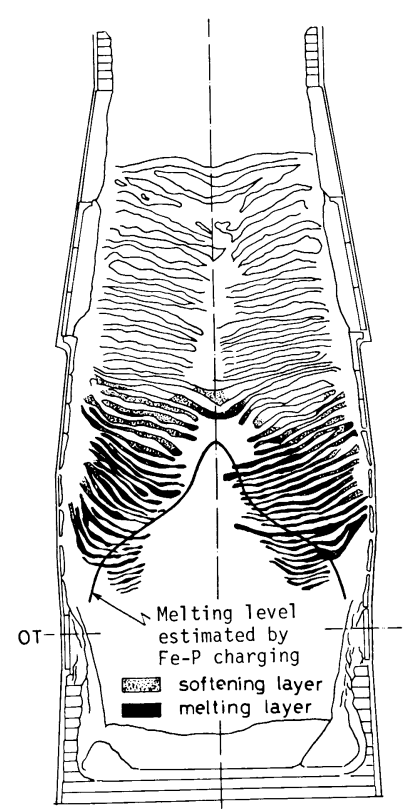

Fig. 9. Comparison of estimated profile of melting zone with observed one after dissection of Kakogawa No. 1 blast furnace.

観察絬果を Fig. 9 に比較して示した. 解休調查は $90^{\circ}$ 扇型の 2 つの断面について行い, 融着層は目視観察によ り融着が進行して苻盤と化した溶融層 (melting layer) と, 融着が弱く分離可能な軟化層 (softening layer) の $2 つ の$ 領域に大別して示した. $\mathrm{Fe}-\mathrm{P}$ 合金投入法によつ て推定した滴下開始ラインは実線で示した。これは Fig. 8 の㵜下半径を滑らかな線で結んだものである. 解体断面にみられる鉣不層の溶け落ちレベルは軸対称性 が乱れ，灯下部では融不層の椆辺部からの溶け落ちが見 られるが，Fe-P 全企投入法によつて推定した滴下開始 ラインは解休断洏の㵜ト開始レベルにほぼ一致してい is.

中心部では推定した溶け落ち位置と解体断面にみられ る溶け落七位睢に数層の差がみられる，Fe-P 合金は Fig. 3 に示したよりに $1350^{\circ} \mathrm{C}$ 付近で溶け落ちるが, 鉣石颣の滴卜開始温度はその温度に至るまでの鈗石の還 元辩に依存する ${ }^{9)}$. 两者の滴下開始温度の差が溶け落ち 位置の差となる一つの理由と考えられる.

一J，妆山占上では融着層の周辺部からの溶け落らが みられる。このよらな夙辺部からの一部溶け落ちに対し ては, $S_{\mathrm{m}}(t)$ の変化から考察できる. すなわち, 逆 V 型の溶け落セレベル形状の場合は，Fig. 2 に示したよ うに, 出銑小にリン濃度が最大となる時刻はトレーサー 層の㵜下公了の㭙刻にほぼ一致する。 Fig. 7 の場合,

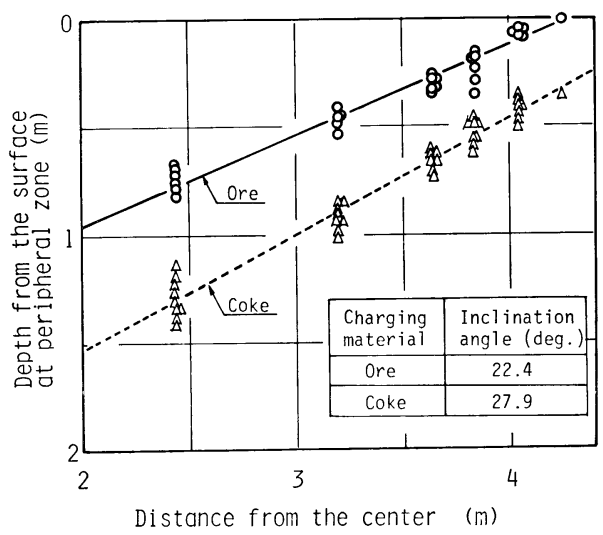

Fig. 10. Surface profile of charging materials measured at the throat.

(13)式で算出される滴下率は, 最大濃度を示す時期では まだ約 70\%である.このことから, 最大濃度を示した 後は周辺から滴下するとして滴下開始位置の推定線を補 正することもできるが，この場合は中心から滴下すると して求めてきた㵜下開始ラインを延長するなどの操作が 必要となる。

これまで, 炉内層構造が水平であると仮定して解析し てきた. 加古川 No. 1 高炉の吹上時にプロフィールメ ーターによつて測定した装入物の堆積形状を Fig. 10 に示すが，ペレット多配合により鈗石層の傾斜角はコー クス層のそれょりも小さく, 半径方向の ore/coke 分布 が生じている.そこで Fig. 10 に示した傾斜角を用い, 著者の一人稲葉が提案した方法 ${ }^{10)}$ 基ついて半径方向の 堆積分布と降下に伴う堆積傾斜角及び層厚の変化を考虑 して解析した. しかし, シャフト下部では層の傾斜角が 水平に近づき, 層厚も減少しているので, 水平な層構造 と仮定した解析結果と大きな差違は認められなかつた。

炉床の希釈効果を一次遅れ系之仮定してトレーサーの 物質収支から㭁内残銑量の初期值を $390 \mathrm{t}\left(\right.$ 約 $57 \mathrm{~m}^{3}$ ) と 推算した。 これは羽口から出銑口問の炬床容積の $14 \%$ に相当する.ここで導出した残銑量は一次遅れ系の時定 数として, 炉床の機能を表わす一つのバラメータと考え られるが，炉床の挙動をより詳細に扱らには溶銑, 溶涬 のホールドアップや溶銑の流路などを考虑した解析が必 要と考えられる。

\section{5. 結} 言

高炉炉内の滴下帯形状，すなわち軟化融着帯の内側形 状を推定するトレーサー法を開発した。 これまでのトレ 一サー法は炉内半径方向のある一点の滴下開始位置を推 定する方法であつたが，ここで開発した方法は，ある一 
層の鉱石層内に均一にトレーサーを添加して炉内に投入

し, 出銑時のトレーサーの濃度変化を解析することによ

り, 炉内の滴下開始レベルの半径方向分布を推定するこ とができる。

トレーサーとして用いた Fe-P 合金は溶け落ち温度 が $1350^{\circ} \mathrm{C}$ で鉱石類の溶け落ち温度に近いので，鉣石 類の滴下位置を追跡するのに有効なトレーサーであると 考えられる.

ここで開発した方法を加古川 No. 1 高炉の吹止直 前 の操業に適用して炉内の滴下帯形状を推定した. この推 定結果を検証するためにこの高炉の解体調査を行い, 断 面の観察結果と比較したところ，かなり良い一致をみる ことができた.

また，このトレーサー法は炉床部における残銑量の変 化を考慮しているので間歇出銑の高炉にも適用できると 推察される. しかし，この推定法は炉内状況の軸対称性 と炉床部の完全混合一次遅れ系を仮定しているので，炉 内状況の円周方向のバランスがとれ, 炉床部の液ホール ドアップの変動の少ない連続出銑の高炉に対して, ょり 精度よく適用できると考えられる.

\section{文献}

1) 福島勤, 下田輝久：润灿内現象と关の解析（日

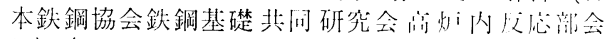
編）(炤和 54 年 10 月), p. 5


之鋼， 65 (1979) 10, p. 1526

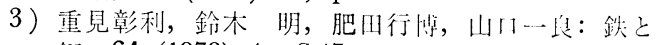
錭, 64 (1978) 4, S 47

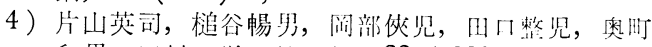
和男，田村 栄：鉄と龬，66 (1980) 11，：682

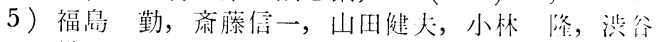
悌二，古川武，山口䉆：鉄之鍓，67 (1981) 4, S 69

6）下村泰人，九島行正，有野俊行：鉄と銅，62 (1976) 4, S 65

7 ）日本鉄鋼協会共同研究会：筗５3回製銑部会 $(1978 \cdot 10)($ 私信 $)$

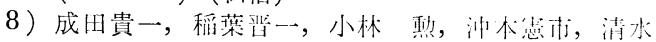

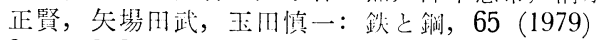
3 , p. 358

9) 成田貴一, 前田昆大, 清水正婜：鉄と銅，63 (1977) 11, S 486

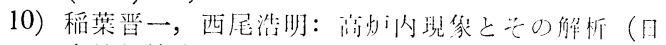

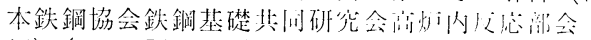
練) (炤和 54 伴 10 川), p. 52 